\title{
Enhancing the Performance of Andragogic Education
}

\author{
Valentina Sinelnikova ${ }^{1,},{ }^{*}$, Tatiana Ivchenko ${ }^{2}$, Tetana Pistunova ${ }^{1}$, Nataliya Regesha $^{1}$ \& Marharyta Skazhenyk $^{1}$ \\ ${ }^{1}$ Department of Musical Art, Kyiv National University of Culture and Arts, Kyiv, Ukraine \\ ${ }^{2}$ Department of Social Work, State Establishment "Taras Shevchenko Lugansk National University", Starobilsk, \\ Ukraine \\ *Correspondence: Kyiv National University of Culture and Arts, 36, Eugene Konovalets Str., Kyiv, 01601, Ukraine
}

Received: December 9, 2021

Accepted: January 6, 2022 Online Published: January 17, 2022

doi:10.5430/jct.v11n1p245

URL: https://doi.org/10.5430/jct.v11n1p245

\begin{abstract}
The article is devoted to the development of adult education, its andragogical principles and the impact on the quality of lifelong pedagogical education. The authors examined the mechanisms for improving the quality of lifelong pedagogical education by updating the content, developing and implementing innovative teaching technologies following new European guidelines and concepts in education, taking into account national educational traditions. In the article, the authors considered the basic concepts of andragogy, investigated the specifics of andragogical processes, the world experience in adult education. The authors noted that adult education today is based on continuous learning, self-education, and self-development. People will have to retrain 2-3 times in life; they will retrain at least once in adulthood. The research methodology is based on personality-activity and systematic approaches. As a result of theoretical and methodological research, the authors proposed a mechanism based on information technology (distance learning), the principles of androgynous learning and the specific features of adult learning (which the authors divided into three groups). This mechanism can increase the effectiveness of andragogical education in developing an educational trajectory. Further research is the search for ways of state financing of adragogical education and the development of indicators of its effectiveness.
\end{abstract}

Keywords: adult education, andragogy, andragogical principles, continuing education

\section{Introduction}

In the modern information society, certain factors necessitate the constant updating of human education and all knowledge in general (Bessarab et al., 2021; Poplavskyi, 2019). First, it is the development of new technologies, which are, on the one hand, a catalyst for the rapid growth of interpersonal and intergroup communications, and on the other - create an opportunity to change the flow of these communications, thus able to really transform the social structure of society. Secondly, it is the state of the demographic situation in the world, which forces a person to change profession or undergo additional training. And thirdly, it is the strengthening of global migration processes that promote the active exchange of ideas, theories, knowledge and experience. These factors led to the construction of a system of continuing vocational education, covering all active human life. In this case, diversity and continuity are seen as a promising trend and a condition for achieving a new quality of education (Horodovenko et al., 2021). Changes in the education system require lifelong learning skills, cognitive activity, collective learning, and knowledge transfer (Halkiv et al., 2021).

Analyze andragogical principles of adult education and their impact on improving the quality of continuing education by updating the content, development, and implementation of innovative learning technologies according to new European educational guidelines and concepts, taking into account national educational traditions.

The following tasks follow the set goal:

a) to investigate the basic concepts of andragogy;

b) to analyze the features of andragogical approaches in education;

c) to study the world experience in adult education.

By examining these three areas, a foundation will be established to enhance andragogic education performance. 
The theoretical basis of the research is:

- the provisions of philosophy, psychology, sociology, pedagogy, revealing the general scientific concept of "interaction" as a subject of interdisciplinary study, as a phenomenon that integrates the aspects of a person's value assimilation of the surrounding reality, the transformation of subjects in joint activities (Thorndike, 1913; Nesbit et al., 2020);

- the concept of subjectivity in psychology and pedagogy (Thorndike et al., 1928);

- andragogical approach in pedagogy, a set of scientific ideas about adult education (Blondy, 2007; Billington, 2020;

Foley, 1999; Thorndike, 1913);

- ideas of a competence-based approach in vocational education (Dentith \& Thompson, 2017; Prokopenko et al., 2020);

- works of scientists on the problems of additional vocational education and training of teaching staff (Ekoto \& Gaikwad, 2015; Rainie, \& Anderson, 2017);

- modern scientific works devoted to the interaction of subjects of the educational process in teaching adults (Orazbaeva, 2021; Nesbit et al., 2020; Foley, 1999).

Processes in society show that we will have to retrain 2-3 times in life (Rainie \& Anderson, 2017), i.e. we will retrain at least once as an adult, thus, improving the performance of andragogic education is relevant.

\section{Literature Review}

\subsection{Basic Concepts of Andragogy}

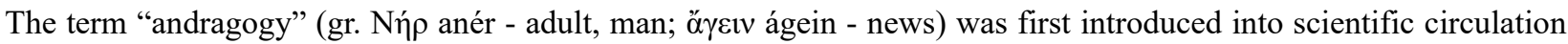
in 1833 by the German historian A. Kapp (Loeng, 2017). Almost simultaneously with his German colleague proved that regardless of the level of a person's training, his ability to learn at the age of 22-45 is at a certain little-changing stable level (Thorndike, 1913; Thorndike et al., 1928).

Teaching, according to modern andragogy, should be structured in such a way as to minimize the role of the teacher, who, although he manages this process, uses didactic techniques and methods less often. Andragogy moderates the educational process, referring primarily to the stated individual goals of each student. Knowles' research captures the differences in teaching between students and adult groups. For example, the educational process in andragogy received an original model different from the pedagogical one. The content of the training has also changed. Lecture hours are shortened, and practical classes, seminars, discussions, case studies, business games are becoming the preferred form of analysis. In the content field, andragogy prioritizes complex (interdisciplinary) studies over theoretical ones.

It should be noted that andragogy as a science has its concepts. The conceptual and terminological apparatus of andragogy includes more than 800 terms. Of course, these terms do not exist separately and autonomously from other sciences. Among the basic concepts of andragogy, we can single out the following: "adult education", "continuing education", "self-education", "self-improvement", "self-development" and others. Consider the main ones:

- adult education - a component of the education system, its relatively separate unit, the main task of which is to promote the comprehensive development of man during his independent life;

- continuing education is a purposeful and coordinated system of education and upbringing in the conditions of scientific, technical and social progress, adequate to its modern content, the essential characteristic features of which are the lifelong process of independent learning, upbringing and orientation on knowledge acquisition; constant updating of the content of education; the combination of training with practical activities; permanent self-education;

- self-education (in a broad sense) - is a conscious, planned and self-regulated independent cognitive activity of the individual, aimed at the harmonious development and satisfaction of cognitive interest or motivated by the desire to learn something, increase the adaptability of professional activity or learn a new activity;

- self-improvement - a process of conscious development controlled by the person himself, in which, in the interests of the person himself, as well as subjective purposes, his qualities and abilities are purposefully formed and developed (Orazbayeva, 2021);

- self-development of personality - the process of enriching man's abilities and personal qualities in the course of 
various appropriate activities. The basis of self-development is the assimilation of social experience and cultural achievements embodied in the realities involved in a particular activity. Two factors determine the course of self-development and its results:

a) the individual's ability to work "with knowledge", i.e. the quality and level of education;

b) the nature and extent of the implementation of socio-cultural experience in the realities with which the subject of activity.

Thus, the object of andragogy is all the phenomena of reality that determine an adult's development in society's purposeful activity. That is, the object of andragogy should be considered multifaceted continuing adult education, which is carried out in the institutions of formal, non-formal and informal education following socio-cultural conditions.

\subsection{Features of Andragogical Approaches in Education}

Modern science identifies the following basic principles of andragogy (Figure 1):

1. The principle of priority of self-study provides an adult with the opportunity to get acquainted with educational materials slowly, memorize terms, concepts, classifications, and understand the processes and technologies of their implementation. Modern distance learning provides significant assistance in this.

2. The principle of joint activity. Supporting each other is a fundamental fact of effective learning.

3. The principle of systematic learning. It consists in the conformity of the purposes and the maintenance of training to its forms, methods, means of training and estimation of results.

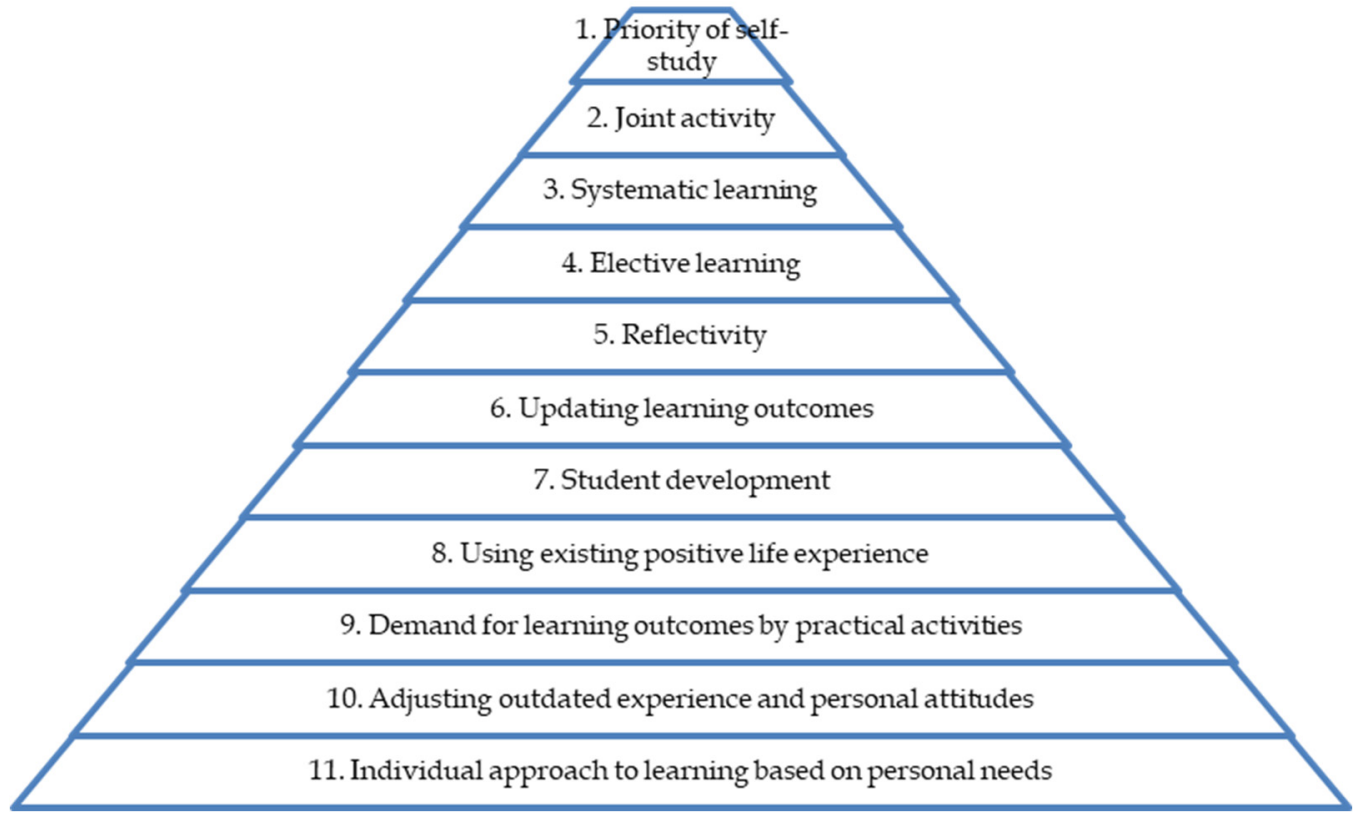

Figure 1. Basic Principles of Andragogy

4. The principle of elective learning (giving students the freedom to choose goals, content, forms, methods, sources, means, timing, time, place of study, evaluation of learning outcomes).

5. The principle of reflectivity. This principle is based on the student's conscious attitude to learning, which, in turn, is a significant part of the student's self-motivation.

6. The principle of updating learning outcomes (their rapid use in practice).

7. The principle of student development. Training should improve the personality, create abilities for self-learning, and understand the new in practical human activity.

8. The principle of using existing positive life experience (exceptionally social and professional), practical knowledge, skills, learning skills. Individual work is a dialogue between student and teacher, aimed at mutual transfer of information and knowledge. At the same time, the formalization of empirical knowledge is carried out. 
9. The principle of demand for learning outcomes by practical activities of the student.

10. The principle of adjusting outdated experiences and personal attitudes prevents acquiring new knowledge.

11. The principle of individual approach to learning based on personal needs, taking into account the socio-psychological characteristics of the person and the limitations imposed by his activities, the availability of free time, financial resources, etc.

\subsection{World Experience in Adult Education}

The importance of adult education in the modern world is emphasized by the creation of international and national centres for adult education: UNESCO Institute for Education (Hamburg); International Institute for Educational Planning (Paris); International Institute of Education (USA); Swiss Organization for Adult Education; International Pedagogical Center (France); National Institute for Adult Education (UK); International Institute for Educational Research (Germany), etc.

The United Nations have emphasized the social importance of adult education - UNESCO since its inception (Brill, 2021). In 1976, at the 19th session of the UN General Conference on Education, Science and Culture in Nairobi, a Recommendation on the Development of Adult Education was developed. The ideas of which continue to be discussed at all subsequent international conferences on adult education.

Of particular importance was the Fifth International Conference on Adult Education in Hamburg (Germany) on July 14-18, 1997, which adopted the Hamburg Declaration on Adult Education and the Agenda for the Future.

The international conferences that followed in Sofia (2002), Bangkok (2003), regional in Tashkent (2003) discussed the problems of adult education in the spirit of the ideas of the Hamburg Conference, in the development, concretization, clarification of its concepts.

The International Conference on Adult Education in Hamburg notes positive trends in policy towards indigenous populations, highlighting four "pillars of education":

- learning to live, or the right to identity;

- learning to know, or the right to self-education;

- learning to do, or the right to self-development;

- learning to live together, or the right to self-determination.

International cooperation and solidarity in adult education in the new century, through partnerships, shared exchange and networking, aims to improve the effectiveness of human development programs to:

- promote lifelong learning for adults through a sectoral and intersectoral approach;

- maximize opportunities for adult learning by integrating adult learning components into all programs and projects;

- increase the opportunity for non-traditional populations to participate in learning opportunities actively.

To summarize, the International Adult Education System is currently characterized by:

- the use of information technology;

- expansion of the private sector in the provision of educational services;

- aggravation of competition between state educational institutions and private organizations in the provision of services and in obtaining funding;

- non-profit organizations that focus their activities on programs for low-income and problem groups of the population, their efforts are aimed at forming a civil society in the world;

- increased attention to vocational training in large firms and industrial associations;

- understanding the benefits for the state of investing in education, which will give a good result not only in the socio-psychological atmosphere of society but also in the material sphere;

- a broad understanding of the problem of cooperation also needs to be learned at all levels of society (Walker, 2020; Bashynska et al., 2021; Oktay \& Okur, 2021; Savenko, 2021).

Studied theoretical basis allows developing recommendations to improve the effectiveness of andragogic education. 


\section{Methods}

The research methodology is based on:

- personality-activity approach (Ihnatenko \& Pylypei, 2019; D’Souza \& Fernandes, 2021; Vikulova et al., 2021), which was used as a basis for determining the characteristics of a teacher as a subject in the context of designing one's professional self-development in the process of professional retraining, it made it possible to take into account the subjective experience of pedagogical workers in the implementation of andragogical interaction in the educational process of professional retraining;

- a systematic approach (Bondar et al., 2021; Demakova \& Shustova, 2021; Vezne \& Y1ld1z, 2021), based on which the educational process of teachers' professional retraining was considered a system in which andragogical interaction of subjects is realized.

\section{Results}

Processes in society show that we will have to retrain 2-3 times in life, i.e. we will retrain at least once as an adult. Moreover, this generation has grown up on information technologies, so they should become the leading tools for improving andragogical education. In connection with the development of information technology, improving the effectiveness of andragogy education requires certain specifics (Figure 2).

Let us dwell on the elements of the proposed scheme for improving andragogical education. First of all, it is worth describing in more detail the features of adult education, which have a significant impact on performance. We divided them into three groups:

The first group of features is associated with increased competence (involves self-analysis and self-assessment of professional educational activities).

Specific features of the adult group: has a certain amount and level of general and professional knowledge in one or more subject areas; has formed professional work experience and develops it; possessing specific receptions, abilities and skills, carries out self-analysis and self-assessment of educational professional activity; has his own professional opinion and defends it from his position; conscious in the development of its competence, has a pronounced ability to generalize and set new tasks in the structure of intelligence; solves vital problems through training; seeks to implement the acquired knowledge quickly, and for this purpose has specific areas of their application (or otherwise plans where to use them); determines its educational activity by temporary, social, professional, household factors; economical to the time spent on training; seeks to memorize new knowledge, information in accordance with their relevance and significance; is aware of the decline of his professional activity in the context of new requirements for its development, tries to solve the problem; ambiguous in the self-analysis of their professional and educational activities.

The second group of features is related to the personal status of an adult.

Specific features of the adult group: self-awareness as an independent, self-regulating personality, self-affirmation, self-realization; inner freedom; moral and social maturity; significant emotional involvement in the realities of life; breadth of social roles; psychological maturity; physiological maturity; increased verbalization (the ability to express their condition in words); life experience; financial independence; significant compromise in decision-making; moral, legal and social responsibility (to one degree or another); clarity, the intensity of interests.

The third group of features is associated with certain barriers to the perception of educational activities (in life, they are inherent in everyone).

Specific features of the adult group: complicated (with age) attitude to education (formed the basic values of adult life in their transformation in the learning process are perceived painfully); lack (or insufficiency) of skills, abilities to learn; difficulties in abandoning the system of permanent, previously acquired knowledge, obsolete at the moment; the attitude that they know everything (barriers to prejudice against innovation and change are set); the difficulty of changing the existing status (especially of the administrative staff) to the role of a student; internal uncertainty in reducing their "professional self-esteem" in the process of the need to restructure their activities to meet new requirements, for example, in today's market conditions (feels in the self-analysis of professional and educational activities). 


\begin{tabular}{|c|c|c|c|c|}
\hline \multicolumn{5}{|c|}{ specific personality traits of adult students } \\
\hline$\sqrt{7}$ & \multicolumn{4}{|c|}{ Specific features $\checkmark$ of the adult student } \\
\hline $\begin{array}{l}\text { I group is associated with } \\
\text { increased competence (involves } \\
\text { self-analysis and self-assessment of } \\
\text { professional educational activities) }\end{array}$ & \multicolumn{2}{|c|}{$\begin{array}{l}\text { II group is related to the personal } \\
\text { status of an adult }\end{array}$} & \multicolumn{2}{|c|}{$\begin{array}{l}\text { III group is associated with specific } \\
\text { barriers to the perception of } \\
\text { educational activities (in life, they } \\
\text { are inherent in everyone). }\end{array}$} \\
\hline \multicolumn{5}{|c|}{ Stages of design and implementation of adult learning technologies } \\
\hline \multicolumn{5}{|c|}{ 1. Psychological and andragogical diagnosis } \\
\hline \multicolumn{5}{|c|}{$\begin{array}{l}\text { The stage of diagnosis (psychological and andragogical) of the subject of study, determination of its cultural } \\
\text { and educational needs, socio-psychological and cognitive features, construction of a forecast of probable } \\
\text { development, education, changes. This stage is the initial one. Its purpose is to obtain the information } \\
\text { necessary for the further activities of the subjects of pedagogical interaction. }\end{array}$} \\
\hline \multicolumn{5}{|c|}{ 2. Planning, selection (development) of optimal technology } \\
\hline \multicolumn{5}{|c|}{$\begin{array}{l}\text { Considering the information about the student's individuality, his educational and cultural needs, the choice } \\
\text { of one of the available educational technologies is made; individualization of this technology; development } \\
\text { of a new, individual learning trajectory. }\end{array}$} \\
\hline \multicolumn{5}{|c|}{ 3. Direct preparation for the implementation of the chosen learning trajectory } \\
\hline \multicolumn{5}{|c|}{$\begin{array}{l}\text { Identification of the material, technical, etc., inadequacies that may adversely affect the performance of the } \\
\text { developed educational technology to prevent possible difficulties in its implementation, ensuring its } \\
\text { effectiveness and quality. }\end{array}$} \\
\hline \multicolumn{4}{|c|}{ 4. Technological } & \\
\hline \multicolumn{5}{|c|}{$\begin{array}{c}\text { The actual implementation of the trajectory of adult learning. This stage is the main one. The whole set of } \\
\text { preliminary measures was carried out in order to ensure its effectiveness. }\end{array}$} \\
\hline \multicolumn{4}{|c|}{ 5. Evaluation } & \\
\hline \multicolumn{5}{|c|}{ A stage allows evaluating the result of the introduction of adult learning technology and all the work done. } \\
\hline \multicolumn{4}{|c|}{ 6. Corrective } & \\
\hline \multicolumn{5}{|c|}{$\begin{array}{l}\text { Making changes in the content, means, forms, teaching methods, evaluation of its results, etc., to correct } \\
\text { pedagogical interaction of design and implementation of adult learning technologies. }\end{array}$} \\
\hline \multicolumn{3}{|l|}{ 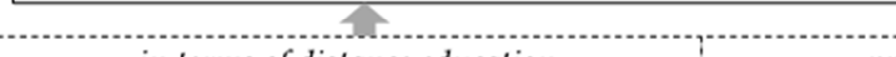 } & inciples & $g \circ y$ \\
\hline \multicolumn{2}{|c|}{$\begin{array}{l}\text { 1. Relevance of training; } \\
\text { 2. Focus on the immediate application of knowledge; } \\
\text { 3. Identification and consideration of personal } \\
\text { experience and knowledge of the student; } \\
\text { 4. Correction and expansion of student knowledge; } \\
\text { 5. Individualization and flexibility of learning; } \\
\text { 6. The leading role of the student in learning } \\
\text { 7. The importance of interdisciplinary knowledge; } \\
\text { 8. Cooperation in education. }\end{array}$} & \multicolumn{3}{|c|}{\begin{tabular}{|c|} 
1. Priority of self-study; 2 . Joint activity; \\
3. Systematic learning; 4 . Elective learning; \\
5. Reflectivity; 6 . Updating learning outcomes; \\
7. Student development; 8 . Using existing positive \\
life experience; 9 . Demand for learning outcomes \\
by practical activities; 10 . Adjusting outdated \\
experience and personal attitudes; \\
11. Individual approach to learning based on \\
personal needs
\end{tabular}} \\
\hline
\end{tabular}

Figure 2. Mechanism for Increasing the Efficiency of Andragogic Education

The principles of andragogical education are considered in detail in the theoretical section (Fig. 1), so consider the generalized features of adult learning in distance education:

1. Relevance of training.

Correspondence of the content of education to the development of society and technologies, modern needs of the labour market. Training should meet the current challenges of mastering new technologies in production, improving the professional activities of specialists, training and retraining. The connection between training and job responsibilities is becoming more and more critical. At the level of an adult student, learning should meet his needs, goals, position, directly help to perform professional duties. The constantly growing volumes of information should be taken into account in the TN of adults. Relevance of educational content, convenient methods of its updating and 
maintenance. Modelling of personnel and production tasks, modelling of competencies, positions, professions. Establishing a correspondence between competencies and training materials.

2. Focus on the immediate application of knowledge.

The peculiarity of adult learning is expressed in the need for justification or meaning of learning. Training should be relevant, based on personal needs in solving practical jobs, production problems, and personal and professional development. The principle of updating learning outcomes is that an adult seeks the fastest application of the acquired knowledge and skills - relevance of educational content, convenient methods of its updating and maintenance. Apply links between adult learner skills and learning content. Modelling skills and competencies and their relationship to learning content Relevant to the professional needs of the student presentation of course content.

3. Identification and consideration of personal experience and knowledge of the student.

Identification, systematization and formalization of existing personal experience, knowledge of the student to use them to build an appropriate learning process. An adult has professional and life experience, knowledge and skills that must be used and taken into account in training. Methods of diagnosing, monitoring and modelling knowledge, skills of the student. Modelling of learning conditions. Introduction of methods of construction of a training course based on previous training conditions.

4. Correction and expansion of student knowledge.

The function of the teacher - correction, expansion of knowledge of the student taking into account the systematization of knowledge, compliance with learning objectives. In contrast, primary education is characterized by presenting knowledge "from scratch" and in full. Modelling of goals, knowledge and skills of the student. Methods of constructing training courses by students' goals, taking into account the already formed knowledge and skills. Modelling of positions and competencies. Ways of building relevant courses to overcome the intervals between competencies.

5. Individualization and flexibility of learning.

The principle of individual approach to learning is based on personal needs, taking into account the socio-psychological characteristics of the individual and the limitations imposed by professional activities, availability of free time, financial resources and more. Ability to adapt the content of education to the needs of students, the choice of content by the problem stated by the student, taking into account the interests of students. Modelling of educational needs and goals of the student. Diagnosis, control and modelling of knowledge, skills of the student. Socio-psychological modelling of the student. Adaptation of the educational process based on information about the student and his current academic achievements.

6 . The leading role of the student in learning.

The leading role in the learning process is played not by the teacher but by the student. Achieving learning outcomes - through the personal acquisition of knowledge. Priority of independent learning. Ensuring the manageability of the learning process by the student. The ability for students to choose the direction of study. Active use of social networks and electronic communication.

7. The importance of interdisciplinary knowledge.

The first place is occupied by disciplines that contain integrated material from several related fields of knowledge (interdisciplinary disciplines). Support for interdisciplinary connections in educational materials. Modelling of educational content.

8. Cooperation in education.

The importance of cooperation between students and teachers. Support for team activities, electronic communication, educational community. Modelling of social, educational networks. Introduction of technologies of "artificial classmates", personalized assistants, etc.

This mechanism can increase the effectiveness of andragogical education, so it or its elements must be considered in the formation of programs and the trajectory of adult learning.

\section{Discussion}

It is important to emphasize that every person at any period of his life should have the opportunity to participate in the educational process. On the basis of continuity, it was possible to build a unified model of education, which 
includes vocational training, general cultural development and civic education. The study distinguishes a practical, systematic approach to improving anragogical education instead of an approach through the theoretical lens of andragogical theory (Akintolu \& Letseka, 2021). The debatable aspect is the synergetic effect of adragogical and dual education, as in the study by Bashynska et al. (2021). A distinctive feature of the proposed mechanism is Iago universality for both sexes, in contrast to the emphasis on the male field in the study by Rismiyanto et al. (2018).

Continuing education is developing in two directions. Life-long education implies that learning opportunities should be uniform throughout a person's life and should not have a clear beginning and end. Life-wide education means the availability of all basic educational and cognitive activity forms for every person and for all social groups without exception. At the same time, self-education becomes one of the main activities. The proposed mechanism covers these two areas.

\section{Conclusions}

Meeting the requirements of modern society, which arise with the introduction of new equipment and technologies, requires adequate training approaches, including the use of optimal forms and teaching methods. Thus, scientists and practitioners have proven the feasibility of using adult andragogical models of learning, which considers the characteristics of this category of students: age, psychophysiological, professional, and others.

Thus, the adult education system under the influence of socio-economic changes taking place in society shows a tendency to focus not only on the state's requirements but also on the personal and professional needs of teachers themselves. It is aimed at updating the entire system of continuous professional development of heads and teachers of secondary schools, namely: to take into account trends in society, to master new content and pedagogical technologies, to introduce distance learning and information technology, innovation, to develop the ability to compare local problems their managerial and pedagogical activities with national priorities, on the motivation of their professional growth. All this necessitates new approaches to understanding the activities of andragogues, their mastery of modern technologies of adult education and professional development.

The introduction of the proposed mechanism will improve the practical training of the adult population, allowing it to compete in the market with young specialists. The improvement of knowledge of information technology will meet the requirements of employers.

Further research is the search for ways of state financing of adragogical education and the development of indicators of its effectiveness.

\section{References}

Akintolu, M., \& Letseka, M. (2021). The andragogical value of content knowledge method: the case of an adult education programme in Kwa-Zulu Natal Province of South Africa. Heliyon, 7(9), e07929. https://doi.org/10.1016/j.heliyon.2021.e07929

Bashynska, I., Garachkovska, O., Kichuk, Ya., Podashevska, T., \& Bigus, O. (2021). Smart Education 4.0: Balancing Dual-Distance and Reskilling Revolution. Studies of Applied Economics, 39(6), 1-11. https://doi.org/10.25115/eea.v39i6.5262

Bessarab, A., Mitchuk, O., Baranetska, A., Kodatska N., Kvasnytsia, O., \& Mykytiv, G. (2021). Social networks as a phenomenon of the information society. Journal of Optimization in Industrial Engineering, 14(1), 35-42. https://doi.org/10.22094/JOIE.2020.677811

Billington, D. D. (2000). Seven Characteristics of Highly Effective Adult Learning Programs. Retrieved from http://www.umsl.edu/ henschkej/henschke/seven_characteristics_of_highly_effective_adult_learning_programs .pdf

Blondy, L. C. (2007). Evaluation and Application of Andragogical Assumptions to the Adult Online Learning Environment. Journal of Interactive Online Learning, 6(2), 116-130.

Bondar, I., Komarnitskyi, I., Rusavska, V., Batchenko, L., \& Honchar, L. (2021). Formation and development of digital skills in university education: a systematic approach. Laplage in Review, 7(B), 47-56. https://doi.org/10.24115/S2446-622020217Extra-B882p.47-56

D'Souza, R., \& Fernandes, N. (2021). A Perspective on an Interdisciplinary Approach to Education. Modern Perspectives in Language: Literature and Education, 8, 105-113. https://doi.org/10.9734/bpi/mplle/v8/4067F 
Demakova, I., \& Shustova, I. (2021). Systematic Approach for Efficient Use of Research Methods in Educational Theory. Education and Self Development, 16(3), 249-260. https://doi.org/10.26907/esd.16.3.22

Dentith, A., \& Thompson, P. (2017). Teaching Adult Ecojustice Education. New Directions for Adult and Continuing Education, 153, 65-75. https://doi.org/10.1002/ace.20222

Ekoto, C. E., \& Gaikwad, P. (2015). The Impact of Andragogy on Learning Satisfaction of Graduate Students. American Journal of Educational Research, 3(11), 1378-1386.

Foley, G. (1999). Teaching adults. In Foley, G. (Ed.), Understanding Adult Education and Training (pp. 71-98). London: Routledge. https://doi.org/10.4324/9781003118299-5

Halkiv, L., Karyy, O., Kulyniak, I., Kis, Y., \& Tsapulych, A. (2021). The national system of higher education and government procurement for its services as activators of the development of IT entrepreneurship. CEUR Workshop Proceedings, 2870, 1338-1349.

Horodovenko, V., Bilovodska, O., Vatras, V., Kanzafarova, I., \& Melnyk, R. (2021). Improving the quality of higher education based on the positive image of hee in the social and information space: Legal and management aspects. Applied Economics Studies, 39(7). https://doi.org/10.25115/eea.v39i7.4996

Ihnatenko, V., \& Pylypei, Yu. (2019). Personality-activity approach to autonomous formation of the competence in translation. Scientific journal of NPU named after M. P. Drahomanov, 72(1), 207-210. https://doi.org/10.31392/NPU-nc.series5.2020.72-1.45

Brill. (2021). United Nations, International Labour Law Reports Online. https://doi.org/10.1163/22116028-03901013

Loeng, S. (2017). Alexander Kapp - the first known user of the andragogy concept. International Journal of Lifelong Education, 36(6), 629-643. https://doi.org/10.1080/02601370.2017.1363826

Nesbit, T., Leach, L., \& Foley, G. (2020). Teaching Adults. In Foley, G. (Ed.), Dimensions of Adult Learning (pp. 22-24). London: Routledge. https://doi.org/10.4324/9781003115366-7

Oktay, Ö., \& Okur, R. (2021). Old Age Adult Education Systems and Refreshment University. Kastamonu Journal of Education, 29(4), 68-91. https://doi.org/10.24106/kefdergi.780577

Orazbaeva, G. (2021). Self-improvement and self-realization of a student as a person. The Way of Science, 88(6), $79-81$.

Retrieved

from https://www.researchgate.net/publication/354806835_SELF-IMPROVEMENT_AND_SELF-REALIZATION_ OF_A_STUDENT_AS_A_PERSON

Poplavskyi, M. (2019). Entrepreneurship in the field of art business in the European Union. Journal of Entrepreneurship Education, 22(6). $\quad$ Retrieved from https://www.abacademies.org/articles/entrepreneurship-in-the-field-of-art-business-in-the-european-union-8819. html

Prokopenko, O., Osadchenko, I., Braslavska, O., Malyshevska, I., Pichkur, M., \& Tyshchenko, V. (2020). Competence approach in future specialist skills development. International Journal of Management, 11(4), 645-656. https://doi.org/10.34218/IJM.11.4.2020.062

Rainie, L., \& Anderson, J. (2017). The Future of Jobs and Jobs Training. Retrieved from https://www.pewresearch.org/internet/2017/05/03/the-future-of-jobs-and-jobs-training/

Rismiyanto, S., Mursid, M., \& Januarius, W. (2018). The Effectiveness of Andragogically Oriented Teaching Method to Improve the Male Students' Achievement of Teaching Practice. English Language Teaching, 11(2), 113-121. https://doi.org/10.5539/elt.v11n2p113

Savenko, O. (2021). The influence of globalization processes on the development of the adult education system. Problems of Education, 2(95), 25-39. https://doi.org/10.52256/2710-3986.2-95.2021.02

Thorndike, E. L. (1913). Educational psychology. New York: Teachers College, Columbia University.

Thorndike, E. L., Bregman, E. O., Tilton, J. W., \& Woodyard, E. (1928). Adult learning. New York: The Macmillan Company.

Vezne, R., \& Yildız, A. (2021). Comparative Analyses of Adult Education Systems of England, Denmark, and Turkey in the Context of the Lifelong Learning Policies of the European Union. Ankara University Faculty of Educational Sciences Journal, 54, 313-334. https://doi.org/10.30964/auebfd.687444 
Vikulova, L., Gerasimova, S., Makarova, I., \& Vishnevskaya, E. (2021). Multimedia Study Aids in Teaching Creative Foreign Language Reading: Personal-Activity Approach. Conference TSNI 2021: Focus on Students' National Identity, 1082-1093. https://doi.org/10.3897/ap.e4.e1082

Walker, J. (2020). Comparing adult education systems: Canada and Aotearoa New Zealand. Journal for Research on Adult Education, 43(2), 1-17. https://doi.org/10.1007/s40955-020-00158-z

\section{Copyrights}

Copyright for this article is retained by the author(s), with first publication rights granted to the journal.

This is an open-access article distributed under the terms and conditions of the Creative Commons Attribution license (http://creativecommons.org/licenses/by/4.0/). 